\title{
Heavy metals investigation in bovine tissues in Brazil
}

\author{
Juarez Fabiano ALKMIM FILHO ${ }^{1}$, Amarildo GERMANOํㅜㄴ, Wagner Lutero Souza DIBAI', \\ Eugênia Azevedo VARGAS ${ }^{1}$, Marília Martins MELO ${ }^{2 *}$
}

\begin{abstract}
The aim of this study was to investigate the presence of arsenic, lead, and cadmium residues in samples of liver, kidney, and muscle of cattle during the years of 2002 to 2008. A total of 1017 samples from 20 Brazilian States were used. The samples were analyzed at the National Agricultural Laboratory using the atomic absorption spectrometry technique. Arsenic residues were detected in $15.7 \%$ of liver samples and $28.7 \%$ of kidney samples although no results have exceeded the MRL. With regard to lead, 16 samples of liver and 74 samples of kidney were contaminated (5.2 and 10.9\%, respectively). Among these samples, only one liver and two of kidney samples had lead levels above the MRL. Cadmium was found with levels below the MRL in $12.5 \%$ of the liver samples, and only 3 samples (1\%) were quantified above the MRL. Among the kidney samples, $420(60.8 \%$ of the total tested) had cadmium residues, and five of them exceeded the limits established by legislation. It is concluded that the Brazilian meat meets the legislation requirements without putting consumer's healthy at risk since as it satisfies the national and international food-safety conditions.
\end{abstract}

Keywords: atomic absortion spectrophometer; trace elements; arsenic; cadmium; lead.

\section{Introduction}

Brazil is one of the largest producers and exporters of meat in the world; it has established itself as an important international food market. The requirements to access foreign markets, especially the European Union, have been increasing each year. Among the problems of the Brazilian meat industry, one of the most important is undoubtedly the presence of contaminants in the animal tissues, such as the trace elements arsenic, lead, and cadmium.

Arsenic is a metalloid that occurs in different inorganic and organic forms, which are found in the environment both from natural occurrence and from anthropogenic activity. The inorganic forms of arsenic are more toxic as compared to the organic arsenic, but so far most of the occurrence data in food collected in the framework of official food control are still reported as total arsenic without differentiating the various arsenic species (European Food Safety Authority, 2009a).

Contamination of animals feed materials with lead cannot be entirely avoided, given its prevalent occurrence in the environment. Animal exposure to lead results mainly from feed, and it is increased when feed materials contain significant amounts of contaminated soil. Cattle and sheep seem to be among the most sensitive animal species with respect to lead toxicities, and individual intoxications resulting from ingestion of feed material originating from polluted areas or accidental ingestions of lead sources including disposed batteries and other industrial waste have been reported (European Food Safety Authority, 2004).

Plants can accumulate these metals in all parts leading to its transference through the food chain. This accumulation is today one of the latest topics of environmental interest due to its potential damage effects on animals and human health (Maiga et al., 2005; Juhasz et al., 2008). The elimination of lead is incomplete and slow, resulting in bioaccumulation in target tissues, especially after long term exposure. Its half-life is approximately 250 days in ewes, between 95 and 760 days in cattle (Mehennaoui et al., 1988; Rumbeiha et al., 2001), and 2 to18 years in humans (Nilsson et al., 1991; Rabinowitz, 1991).

Cadmium is widely distributed in the environment. It is used in products such as plastics, pigments, batteries; it causes injuries via contaminated water, air, and food. Relatively large amounts of cadmium are found in commercial fertilizers containing phosphate and polyethylene pipe water. High cadmium concentration in the soil might lead to a greater absorption by plants, resulting in increased levels of such metal in foods and feeds (Nakamori \& Kaneko, 2013). The International Agency of Cancer Research has classified cadmium as a human carcinogen (Group 1) based on occupational studies. Recent data on general population exposure to cadmium have been statistically associated with increased risk of cancer in lungs, endometrial tissue, bladder, and breast (European Food Safety Authority, 2009b).

Nowadays, Brazil has a National Plan for Control of Residues and Contaminants (PNCRC), supported by the National Agricultural Laboratories, whose goal is to obtain analytical results to support enforcement actions of the Agriculture Defense Department across the food production chain (Brasil, 1999). However, it is important to conduct a research on the occurrence of major contaminants in meat products to determine their frequency and geographic distribution. Thereby, the aim of this study was to investigate the

${ }^{1}$ Laboratório Nacional Agropecuário - LANAGRO MG, Pedro Leopoldo, MG, Brazil

2 Escola de Veterinária, Universidade Federal de Minas Gerais - UFMG, Belo Horizonte, MG, Brazil, e-mail: mariliamm@ufmg.br

${ }^{*}$ Corresponding author 
presence of arsenic, lead, and cadmium in bovine liver, kidneys, and muscles in Brazil.

\section{Materials and methods}

\subsection{Sampling}

A total of 1017 samples from Brazilian slaughterhouse cattle, previously selected between the years 2002 and 2008, were analyzed. The drawing of the slaughterhouses was conducted at random, as determined by the National Programme for Control of Residues and Contaminants (PNCRC), and the samples were collected by federal agricultural inspectors who work in the selected slaughterhouses (Brasil, 1999). All samples were identified with the origin of the slaughtered animals (state and municipality).

The metals investigated in this study were cadmium, arsenic, and lead. All tests were performed at the National Laboratory of Agriculture (LANAGRO -MG) during the years 2002, 2003, 2004, 2005, 2006, 2007, and 2008; samples from 20 Brazilian states and the Federal District or national capital were analyzed.

\subsection{Samples}

The samples consisted of one or more tissues (500 g) selected from a single animal (Brasil, 1999), apparently healthy. The samples were randomly collected from animals immediately after stunning. Proper identification was carried out to ensure that all tissues of the same sample were from the same animal. Tissue samples were evaluated from the liver, kidney, and skeletal muscle. The analyses of the skeletal muscle were performed only when the samples of liver and/or kidneys showed results above the maximum residue limit (MRL). The MRL of arsenic, cadmium, and lead in tissue samples are $1000 \mu \mathrm{g} / \mathrm{kg}, 1000 \mu \mathrm{g} / \mathrm{kg}$, and $500 \mu \mathrm{g} / \mathrm{kg}$, respectively. Immediately after sampling, each tissue was packed in plastic bags (including all tissues that were previously packaged in a larger plastic bag), which were sealed with a rubber band.

After this process, the samples were sent to the National Laboratory of Agriculture (LANAGRO - MG) for analysis.

\subsection{Equipment}

A Perkin-Elmer Analyst 100 (Norwalk, USA) atomic absorption spectrometer, equipped with a Perkin-Elmer model FIAS 400 flow injection system, and a Perkin-Elmer AS 90 autosampler were used. Silicone pump tubes (NaBH4:1.14 mm i.d., $\mathrm{HCl}$ 10\%: $1.52 \mathrm{~mm}$, sample loading and waste: $3.17 \mathrm{~mm}$ ) were used during this study. All other tubes were made of polytetrafluoroethylene. Argon and acetylene were used as carrier gases. An electrically heated quartz tube was used as an atomizer.

\subsection{Test methods}

The test methods used in this study were the same ones used by the Ministry of Agriculture Livestock and Supply (MAPA) in the analysis of inorganic contaminants (United States Department of Agriculture, 2001).The tests were previously validated using standard reference materials specified by the European Union Commission decision (657/2002). Two test methods were used in the present study; one for determination of cadmium and lead and the other for determination of arsenic, both by atomic absorption spectrophotometry.

\section{Cadmium and lead determination}

The limits of detection and quantification defined in the validation procedures for cadmium were $90 \mu \mathrm{g} / \mathrm{kg}$ or CCa and $100 \mu \mathrm{g} / \mathrm{kg}$ or CC $\beta$, respectively. The limits of detection and quantification defined in the validation procedures for lead were $100 \mu \mathrm{g} / \mathrm{kg}$ or CC $\alpha$ and $150 \mu \mathrm{g} / \mathrm{kg}$ or CC $\beta$, respectively.

\section{Arsenic determination}

Flow injection hydride generation atomic absorption spectrometry was used to detect and quantify arsenic residues in animal tissue (liver, muscle and kidneys) using. The limits of detection and quantification were $15 \mu \mathrm{g} / \mathrm{kg}$ or CCa and $30 \mu \mathrm{g} / \mathrm{kg}$ or $\mathrm{CC} \beta$, respectively.

\subsection{Statistical analysis}

This study evaluated the levels of cadmium (Cd), arsenic $(\mathrm{As})$, and lead $(\mathrm{Pb})$ in different tissues (muscle, kidneys, and liver) of cattle from different regions and states in Brazil. Descriptive statistics were used to create charts and Tables. Averages, variances, standard deviations, and the coefficient of variation were determined. The $10^{\text {th }}, 50^{\text {th }}$, and $90^{\text {th }}$ percentiles and frequency distributions were also calculated.

\section{Results and discussion}

A total of 1017 cattle samples were analyzed between the years of 2002 and 2008, (Table 1).

During the seven years of study, the annual number of cattle samples sent to the laboratory ranged from a minimum of 69 in 2005 and to a maximum of 254 in 2008. The states investigated were those where the vast majority of Brazilian cattle herd are found. The sample distribution reflects the uneven distribution of abattoirs and farms in the country. There is a high concentration of beef production in the states of the Midwest and Southeast regions. Therefore, the annual

Table 1. Bovine sample distribution by the collection year.

\begin{tabular}{ccc}
\hline \multirow{2}{*}{ Collection year } & \multicolumn{2}{c}{ Frequency } \\
\cline { 2 - 3 } & $\mathrm{n}$ & $\%$ \\
\hline 2002 & 112 & 11.0 \\
2003 & 74 & 7.3 \\
2004 & 100 & 9.8 \\
2005 & 69 & 6.8 \\
2006 & 189 & 18.6 \\
2007 & 219 & 21.5 \\
2008 & 254 & 25.0 \\
Total & $\mathbf{1 0 1 7}$ & $\mathbf{1 0 0 . 0}$ \\
\hline
\end{tabular}


drawing conducted by PNCRC (Brasil, 1999) distributes the samples taking into consideration the characteristics of their own supply chain (Table 2).

Arsenic residues were detected in $15.7 \%$ of liver samples although no results exceeded the MRL. In kidneys, $28.7 \%$ of samples had quantifiable residues. However, there was no limit violation. As for the lead, 16 samples of liver and 74 samples of kidney were contaminated (5.2 and 10.9\% respectively). Among them, only one sample of liver and two of kidney had lead levels above the MRL. Cadmium was found with levels below the MRL in $12.5 \%$ of the liver samples, and only in 3 samples (1\%) it was quantified in concentrations above the

Table 2. Sample distribution by collection region and state.

\begin{tabular}{lcc}
\hline \multirow{2}{*}{ Region/State } & \multicolumn{2}{c}{ Frequency } \\
\cline { 2 - 3 } North & $\mathrm{n}$ & $\%$ \\
Acre & $\mathbf{9 4}$ & $\mathbf{9 . 2}$ \\
Pará & 21 & 0.3 \\
Rondônia & 43 & 2.1 \\
Tocantins & 27 & 4.2 \\
Northeast & $\mathbf{9}$ & 2.6 \\
Alagoas & 1 & $\mathbf{0 . 9}$ \\
Bahia & 1 & 0.1 \\
Maranhão & 7 & 0.1 \\
Midwest & $\mathbf{6 1 2}$ & 0.7 \\
Goiás & 146 & $\mathbf{6 0 . 2}$ \\
Mato Grosso & 265 & 14.3 \\
Mato Grosso do Sul & 201 & 26.1 \\
Southeast & $\mathbf{1 9 8}$ & 19.8 \\
Espírito Santo & 10 & $\mathbf{1 9 . 5}$ \\
Minas Gerais & 78 & 1.0 \\
São Paulo & 110 & 7.7 \\
South & $\mathbf{1 0 4}$ & 10.8 \\
Paraná & 52 & $\mathbf{1 0 . 2}$ \\
Santa Catarina & 16 & 5.1 \\
Rio Grande do Sul & 36 & 1.6 \\
\hline
\end{tabular}

MRL. Among the kidney samples, $420(60.8 \%$ of the total tested) had cadmium residues and five exceeded the limits of the permitted by legislation (Table 3). The results confirm the tendency of cadmium to accumulate in the kidneys (European Food Safety Authority, 2004). Furthermore, these results allow us to infer that the presence of cadmium is probably due to anthropogenic activities, and that it was acquired by animals through diet. Therefore, this heavy metal represents a dangerous risk regarding the safety of cattle meat products since the majority of samples showed measurable residues.

The average of contamination, percentiles, standard deviations, maximum, and minimum values of the metals found in the liver and kidneys are shown in Table 4 . The values below the detection limit were not used to calculate the average. The average values of arsenic found both in the liver and kidney (27.42 and $30.55 \mu \mathrm{g} / \mathrm{kg}$, respectively) were considered safe and not close to the limit value of $1000 \mu \mathrm{g} / \mathrm{kg}$. With regard to the percentiles, $90 \%$ of the liver samples contained less than $60 \mu \mathrm{g} / \mathrm{kg}$ of arsenic. The maximum value found was $156 \mu \mathrm{g} / \mathrm{kg}$, in agreement with other authors, who found the maximum value of $150 \mu \mathrm{g} / \mathrm{kg}$ in liver samples of cattle (Korsrud et al., 1985). As for the kidney, the maximum value of arsenic found was $155 \mu \mathrm{g} / \mathrm{kg}$, in agreement with the values found in the liver.

With regard to the lead, the averages found in the liver $(231 \mu \mathrm{g} / \mathrm{kg})$ and kidney $(226.96 \mu \mathrm{g} / \mathrm{kg})$ were below the MRL $(500 \mu \mathrm{g} / \mathrm{kg})$. However, the maximum values exceeded the MRL both in the liver and kidney $(660 \mu \mathrm{g} / \mathrm{kg}$ and $800 \mu \mathrm{g} / \mathrm{kg}$, respectively). Moreover, these values were above the maximum values found by Korsrud et al. (1985). In fact, the general concentration of lead found was very low, with only a few samples showing a concentration above the MRL. It is likely that there might be occasional problems of environmental contamination or some contact of any of these animals with sources of lead, such as paints, fluids, and automotive batteries.

Historically, lead in solders and alloys for water pipes (drinking water supplies) and used as antiknocking and in greases and petroleum have been the major source of environmental pollution and contamination of human and

Table 3. Cadmium, arsenic, and lead in bovine liver, kidneys, and muscle.

\begin{tabular}{|c|c|c|c|c|}
\hline Tissue/Metal & Tested samples & Samples not detected & $\begin{array}{c}\text { Samples detected below } \\
\text { MRL }\end{array}$ & $\begin{array}{c}\text { Samples detected above } \\
\text { MRL }\end{array}$ \\
\hline \multicolumn{5}{|l|}{ Muscle } \\
\hline Arsenic & $6(0.6) *$ & $5(83.3)^{* *}$ & $1(16.7)^{* *}$ & - - \\
\hline Lead & $1(0.1)^{*}$ & $1(100.0)^{* *}$ & $0(0.0)^{* *}$ & $0(0.0)^{\star *}$ \\
\hline Cadmium & $2(0.2)^{*}$ & $2(100.0)^{* *}$ & $0(0.0)^{\star *}$ & $0(0.0)^{* *}$ \\
\hline \multicolumn{5}{|l|}{ Liver } \\
\hline Arsenic & $375(36.9)^{*}$ & $316(84.3)^{* *}$ & $59(15.7)^{\star *}$ & $0(0.0)^{\star *}$ \\
\hline Lead & $306(30.1)^{*}$ & $290(94.8)^{* *}$ & $15(4.9)^{\star *}$ & $1(0.3)^{* *}$ \\
\hline Cadmium & $311(30.6)^{*}$ & $269(86.5)^{* *}$ & $39(12.5)^{\star *}$ & $3(1.0)^{\star *}$ \\
\hline \multicolumn{5}{|l|}{ Kidney } \\
\hline Arsenic & $603(59.3)$ * & $430(71.3)^{\star *}$ & $173(28.7)^{\star *}$ & $0(0.0)^{* *}$ \\
\hline Lead & $677(66.6)^{*}$ & $603(89.1)^{* *}$ & $72(10.6)^{* *}$ & $2(0.3)^{* *}$ \\
\hline Cadmium & $683(67.2)^{*}$ & $263(38.5)^{* *}$ & $415(60.8)^{\star *}$ & $5(0.7)^{\star *}$ \\
\hline
\end{tabular}

${ }^{\star}$ Percentage of tested samples in relation to the total of samples (1017). ${ }^{\star *}$ Percentage of test results (not detected, detected, and detected above MRL) in relation to to the total of samples. 
animals. In recognition of the toxic effects of lead, most countries have obliterated the use of organic lead compounds (tetraethyl lead and tetramethyl lead) in the petroleum industry. However, the emission of lead from waste incinerators and waste disposals still remains. Accidental exposure of animals may also result from lead shots (ingested by waterfowl, or ball traps ingested by cattle), disposed linoleum, and from lead containing ornaments, toys, and pigments. Particularly, cattle intoxication resulting from ingestion of disposed batteries has been regularly reported (European Food Safety Authority, 2004).

Mean levels of cadmium were $207.5 \mu \mathrm{g} / \mathrm{kg}$ and $197.0 \mu \mathrm{g} / \mathrm{kg}$ for the liver and kidney, respectively. Some samples exceeded the limits $(2028.0 \mu \mathrm{g} / \mathrm{kg})$. This value is more than twice the value permitted by legislation $(1000 \mu \mathrm{g} / \mathrm{kg})$. The high level of cadmium in the cattle kidney seems to be an evidence of residues of this metal. In an experiment carried out in Spain in 2000 (LopezAlonso et al., 2000), the levels of cadmium found in calves and cows were significantly lower. The average cadmium in liver was $32 \mu \mathrm{g} / \mathrm{kg}$, almost eight times lower than the concentration found in the present study. Despite the different conditions of the experiment and the fact that most of the samples used in the Spanish study came from young animals, the results of the present study indicate a serious problem of cadmium accumulation in the food chain of the Brazilian herd.

Table 5 describes the number of samples tested and quantified (percentages) of each tissue, according to the state and country region. The highest level of arsenic contamination was found in the liver samples from the Southeast region (19.55\%), followed by the Midwest (17.5\%) and the South regions (9.5\%). As for the kidney samples, the highest level of contamination

Table 4. Descriptive measurements of contaminated samples $\left(\mu \mathrm{g} \cdot \mathrm{kg}^{-1}\right)$.

\begin{tabular}{|c|c|c|c|c|c|c|c|}
\hline \multirow{2}{*}{ Tissue / Metal } & \multicolumn{7}{|c|}{ Descriptive measurements } \\
\hline & Minimum & Maximum & P10 & P50 & P90 & Average & SD \\
\hline \multicolumn{8}{|l|}{ Liver } \\
\hline Arsenic & 10.0 & 156.0 & 10.00 & 20.0 & 60.00 & 27.42 & 26.21 \\
\hline Lead & 160.0 & 660.0 & 160.58 & 205.50 & 394.70 & 231.93 & 119.45 \\
\hline Cadmium & 90.0 & 1281.0 & 90.00 & 121.00 & 402.80 & 207.53 & 213.90 \\
\hline \multicolumn{8}{|l|}{ Kidney } \\
\hline Arsenic & 10.0 & 155.0 & 10.00 & 20.00 & 52.20 & 30.55 & 26.10 \\
\hline Lead & 150.0 & 800.0 & 155.50 & 198.50 & 340.00 & 226.96 & 110.28 \\
\hline Cadmium & 90.0 & 2028.0 & 98.10 & 142.50 & 329.00 & 197.75 & 187.61 \\
\hline
\end{tabular}

Table 5. Distribution of samples from different states/regions.

\begin{tabular}{|c|c|c|c|c|c|c|c|c|c|}
\hline \multirow[t]{2}{*}{ Region/ State } & \multicolumn{3}{|c|}{ Muscle } & \multicolumn{3}{|c|}{ Liver } & \multicolumn{3}{|c|}{ Kidney } \\
\hline & Arsenic & Lead & Cadmium & Arsenic & Lead & Cadmium & Arsenic & Lead & Cadmium \\
\hline North & -- & -- & -- & $0^{*} / 25^{* *}(0.0)^{* * *}$ & $1 / 17(5.9)$ & $2 / 17(11.8)$ & $9 / 67(13.4)$ & $6 / 75(8.0)$ & $39 / 75(52.0)$ \\
\hline Acre & -- & -- & -- & -- & -- & -- & $1 / 3(33.3)$ & $0 / 3(0.0)$ & $3 / 3(100.0)$ \\
\hline Pará & -- & -- & -- & $0 / 4(0.0)$ & $0 / 3(0.0)$ & $0 / 3(0.0)$ & $1 / 17(5.9)$ & $1 / 18(5.6)$ & $4 / 18(22.2)$ \\
\hline Rondônia & -- & -- & -- & $0 / 12(0.0)$ & $0 / 5(0.0)$ & -- & -- & $3 / 36(8.3)$ & $22 / 36(61.1)$ \\
\hline Roraima & -- & -- & -- & -- & -- & $0 / 5(0.0)$ & $1 / 29(3.4)$ & -- & -- \\
\hline Alagoas & -- & -- & -- & -- & -- & -- & $0 / 1(0.0)$ & $0 / 1(0.0)$ & $1 / 1(100.0)$ \\
\hline Bahia & -- & -- & -- & -- & -- & -- & $0 / 1(0.0)$ & $0 / 1(0.0)$ & $1 / 1(100.0)$ \\
\hline Maranhão & -- & -- & -- & $0 / 3(0.0)$ & $0 / 3(0.0)$ & $0 / 3(0.0)$ & $0 / 4(0.0)$ & $1 / 4(25.0)$ & $1 / 4(25.0)$ \\
\hline Midwest & $1 / 4(25.0)$ & $0 / 1(0.0)$ & $0 / 2(0.0)$ & $40 / 228(17.5)$ & $11 / 188(5.9)$ & $21 / 188(11.2)$ & $102 / 367(27.8)$ & $53 / 410(12.9)$ & $252 / 416(60.6)$ \\
\hline Goiás & $1 / 2(50.0)$ & $0 / 1(0.0)$ & $0 / 1(0.0)$ & $9 / 50(18.0)$ & $3 / 47(6.4)$ & $3 / 47(6.4)$ & 29/94 (30.9) & $9 / 99(9.1)$ & $53 / 99(53.5)$ \\
\hline Espírito Santo & -- & -- & -- & $0 / 3(0.0)$ & $0 / 1(0.0)$ & $0 / 1(0.0)$ & $2 / 7(28.6)$ & $2 / 9(22.2)$ & $6 / 9(66.7)$ \\
\hline Minas Gerais & $0 / 1(0.0)$ & -- & -- & $8 / 28(28.6)$ & $2 / 25(8.0)$ & $3 / 25(12.0)$ & $13 / 48(27.1)$ & $4 / 52(7.7)$ & $34 / 52(65.4)$ \\
\hline São Paulo & -- & -- & - & $7 / 46(15.2)$ & $1 / 36(2.8)$ & $7 / 41(17.1)$ & $22 / 50(44.0)$ & $3 / 60(5.0)$ & $34 / 60(56.7)$ \\
\hline South & $0 / 1(0.0)$ & -- & -- & $4 / 42(9.5)$ & $1 / 36(2.8)$ & $9 / 36(25.0)$ & $25 / 58(43.1)$ & $5 / 65(7.7)$ & $52 / 65(80.0)$ \\
\hline Paraná & -- & -- & -- & $2 / 17(11.8)$ & $1 / 12(8.3)$ & $2 / 12(16.7)$ & $13 / 32(40.6)$ & $5 / 37(13.5)$ & 28/37 (75.7) \\
\hline Santa Catarina & $0 / 1(0.0)$ & -- & -- & $1 / 3(33.3)$ & $0 / 3(0.0)$ & $1 / 3(33.3)$ & $2 / 12(16.7)$ & $0 / 13(0.0)$ & $12 / 13(92.3)$ \\
\hline Rio Grande do Sul & -- & -- & -- & $1 / 22(4.5)$ & $0 / 21(0.0)$ & $6 / 21(28.6)$ & $10 / 14(71.4)$ & $0 / 15(0.0)$ & $12 / 15(80.0)$ \\
\hline
\end{tabular}

${ }^{*}$ number of contaminated samples. ${ }^{* *}$ Total of analyzed samples. ${ }^{* *}$ Percentage of contaminated samples. 
Table 6. Provenance of the samples above the MRL.

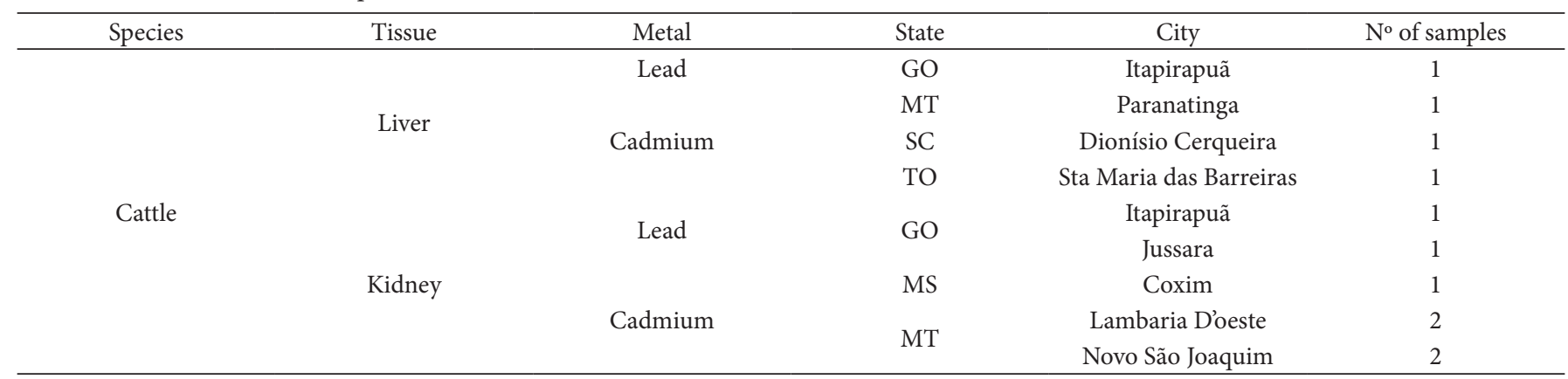

was found in the samples from the South region $(43.1 \%)$, followed by the Southeast and Midwest regions (35.2\% and $27.8 \%$ respectively), with emphasis to those from Paraná and Rio Grande do Sul states, which had $40.6 \%$ and $71.45 \%$, respectively. In the North region, the level of contamination was much lower, but the number of samples in those states was also significantly lower. The same happened with those from the Northeast region of the country, which had no samples contaminated with arsenic; however, the small number of samples used does not allow any conclusion about the level of contamination in this region.

Lead in liver was quantified in $5.9 \%$ of the samples from the North region, $5.9 \%$ of the samples from the Midwest, $4.8 \%$ of the samples from the Southeast, and $2.8 \%$ of the samples from the South region. The samples from the Northeast region were not quantified. The contamination rate in the kidney samples was 8.0, 16.7, 12.9, 7.4, and 7.7\% for the North, Northeast, Midwest, Southeast, and South regions, respectively. Concerning the cadmium levels, the level of contaminated liver samples were $11.8,11.2,14.9$, and 25\% for the North, Midwest, Southeast, and South regions, respectively. The samples from the Northeast region were not quantified. As for the kidney, the number of positive samples ranged from $80 \%$ in the South to $50 \%$ in the Northeast region. In all regions, cadmium was the metal with the highest level of contamination, mainly in the South region of Brazil. There was no direct relationship between physical space and contamination rate. Therefore, the factors leading to heavy metal contamination may be the same across the entire country.

The phosphate rock used in fertilizer production is the major source of cadmium contamination in agricultural soils (Mortvedt, 1987). These same phosphate rocks are used for the manufacture of mineral mixtures used as food for cattle. Thus, it is possible that these sources of anthropogenic contamination also exert their influence in Brazil. It is estimated that the European Union add about 300t/year of cadmium to their soil (Huton \& Symon, 1986), and that the usage of phosphate rocks in the Western United States resulted in the addition of $100 \mathrm{~g} /$ ha/year of cadmium to the soils (Mulla et al., 1980). Residues of cadmium are commonly found in animal viscera, such as in cattle since there is a lifetime accumulation of this metal from the contaminated soil, pastures, and other food (GonzálesWellwe et al., 2006; Gunawardena et al., 2013; Pulles et al., 2012).

\section{Synopsis of samples above the MRL}

During the seven years of study (2002-2008), only 11 out of 1017 tested samples violated the Brazilian law. This low percentage (\%) confirms the efficiency of the National Control Program (PNCRC). However, even with low levels of violation, monitoring is essential since the number of samples with residues was often greater than the number of violations, and in some cases, such as those of cadmium in the kidney samples, the majority of samples contained quantifiable residue, with concentration often close to the limits. Thus, we cannot limit our conclusions to the analysis of the number of samples with concentrations above the permitted limit since these limits can change due to the increase in scientific knowledge about the deleterious effects of these metals for human and animal health (Table 6).

There are many scientific reports about the presence of arsenic, cadmium, and lead in food samples. Nevertheless, this manuscript reports the presence of toxic metals in a considerably large number of samples, randomly collected from numerous farms, which represent well the reality of Brazil.

\section{Conclusions}

The presence of arsenic residues has decreased significantly over time, possibly due to greater control exercised by the government, especially in potential sources of arsenic in the diet, such as organic arsenic. The lead residues in liver, kidney, and muscle were not significant in any of the cattle samples studied. Cadmium contamination has a tendency to increase, which allows us to infer that more effective control measures must be taken to ensure the safety of animal products in relation to this toxic metal even though few samples actually reached the MRL. Violations are possibly related to specific conditions and some sources of contamination on farms, and diet composition is probably the major cause.

\section{References}

Brasil, Ministério da Agricultura. (1999). Programa Nacional de Controle de Resíduos em Produtos de Origem Animal (Instrução Normativa $n^{\circ} 42$, de 20 de dezembro de 1999). Diário Oficial da República Federativa do Brasil. 
European Food Safety Authority - EFSA. (2004). Opinion of the Scientific Panel on Contaminants in the Food Chain on a request from the Commission related to lead as undesirable substance in animal feed. European Food Safety Authority, 72, 1-24.

European Food Safety Authority - EFSA. (2009a). Scientific opinion on arsenic in food. EFSA panel on contaminants in the food chain (CONTAM). European Food Safety Authority, 1351, 1-199.

European Food Safety Authority - EFSA. (2009b). Cadmium in food. Scientific opinion of the panel on contaminants in the food chain. European Food Safety Authority, 980, 1-139.

Gonzáles-Wellwe, D., Karlssson, L., Caballero, A., Hernández, F., Gutierréz, A., Gonzáles-Iglesias, T., Marino, M., \& Hardisson, A. (2006). Lead and cadmium in meat and meat products consumed by the population in Tenerife island, Spain. Food Additives and Contaminants, 33, 757-763. PMid:16807203. http://dx.doi. org/10.1080/02652030600758142

Gunawardena, J., Egodawatta, P., Ayoko, G. A., \& Goonetilleke, A. (2013). Atmospheric deposition as a souce of heavy metals in urban stormwater. Atmospheric Environment, 68, 235-242. http://dx.doi. org/10.1016/j.atmosenv.2012.11.062

Huton, M., \& Symon, C. (1986). The quantities of cadmium, lead, mercury and arsenic entering the UK environment from human activities. Science of the Total Environment, 57, 129-150. http:// dx.doi.org/10.1016/0048-9697(86)90018-5

Juhasz, A. L., Smith, E., Weber, J., Rees, M., Rofe, A., Kuchel, T., Sansom, L., \& Naidu, R. (2008). Application of an in vivo swine model for the determination of arsenic bioavailability in contaminated vegetables. Chemosphere, 71, 1963-1969. PMid:18262220. http:// dx.doi.org/10.1016/j.chemosphere.2007.12.021

Korsrud, G., Meldrum, J., \& Salisbury, C. (1985). Trace element levels in liver and kidney from cattle, swine and poultry slaughtered in Canada. Canadian Journal of Comparative Medicine, 49, 159-163. PMid:4016583 PMCid:PMC1236141.

Lopez-Alonso, M., Benedito, J. L., Miranda, M., Castiillo, C., Hernandez, J., \& Shore, R. F. (2000). Toxic and trace elements in liver, kidney and meat from cattle slaughtered in Galicia (NW Spain). Food Additives \& Contaminants, 17, 447-457. PMid:10932787. http://dx.doi.org/10.1080/02652030050034028
Maiga, A., Diallo, D., Bye, R., \& Paulsen, B. S. (2005). Determination of some toxic and essential metal ions in medicinal and edible plants from Mali. Journal of Agricultural and Food Chemistry, 53, 2316-2321. PMid:15769174. http://dx.doi.org/10.1021/jf040436o

Mehennaoui, S., Charles, E., Joseph-Enriquez, B., Clauw, M., \& Milhaud, G. E. (1988). Indicators of lead, zinc and cadmium exposure in cattle I and II. Veterinary and Human Toxicology, 30, 550-555. PMid:3245119.

Mortvedt, J. J. (1987). Cadmium levels in soils and plants from some long-term soil fertility experiments in United States of America. Journal of Environmental Quality, 16, 137-142. http://dx.doi. org/10.2134/jeq1987.00472425001600020008x

Mulla, D. J., Page, A. L., \& Gange, T. J. (1980). Cadmium accumulations and bioavailability in soils from long-term phosphorus fertilization. Journal of Environmental Quality, 9, 408-412. http://dx.doi. org/10.2134/jeq1980.00472425000900030016x

Nakamori, T., \& Kaneko, N. (2013). Biomarker responses reveal that food quality affects cadmium exposure in soli collembolan Folsomia candida. Environmental Pollution, 176, 165-170. PMid:23421985. http://dx.doi.org/10.1016/j.envpol.2013.01.038

Nilsson, U., Attewell, R., Christoffersson, J. O., Schultz, A., Ahlgren, L., Skerfving, S., \& Mattsson, S. (1991). Kinetics of lead in bone and blood after end of occupational exposure. Pharmacological and Toxicological, 68, 477-484. http://dx.doi. org/10.1111/j.1600-0773.1991.tb01273.x

Pulles, T., Van Der Gon, H. D., Appelman, W., \& Verheul, M. (2012). Emission factors for heavy metals from dieses and petrol used in European vehicles. Atmospheric Environment, 61, 641-651. http:// dx.doi.org/10.1016/j.atmosenv.2012.07.022

Rabinowitz, M. B. (1991). Toxicokinetics of bone lead. Environ. Health Perspect, 91, 33-37. PMid:2040248 PMCid:PMC1519353. http:// dx.doi.org/10.1289/ehp.919133

Rumbeiha, W. K., Braselton, W. E. M., \& Donch, D. (2001). A retrospective study on the disappearance of blood lead in cattle with accidental lead toxicosis. Journal Veterinary Clinical Investigations, 13, 373-378. http://dx.doi.org/10.1177/104063870101300501

United States Department of Agriculture - USDA. (2001). Determination of arsenic by atomic absorption spectrophotometry. Washington: USDA/FSIS. 